\title{
IGA As a Method to Promote Students' Speaking Ability
}

\author{
Ning tyas Orilina Argawati ${ }^{1}$ and Lilis Suryani ${ }^{2}$ \\ ${ }^{1}$ Universitas Pendidikan Indonesia, Bandung, Indonesia \\ ${ }^{2}$ IKIP Siliwangi, Cimahi, Indonesia
}

\section{Abstract}

Speaking is one of productive skills that should be learnt by the students. Nevertheless, the students faced difficulties in speaking. Therefore, Information Gap Activity is offered to solve the students' problem in speaking. This research focuses on implementing IGA in teaching speaking. It aims on describing the implementation of IGA in teaching speaking and discovering the strengths and weaknesses of IGA. This research employed classroom action research. The first researcher acted as a lecturer and the second as an observer. This research was conducted on two cycles; each cycle consisted of three meetings, one pre-test and post-test. The participants of

Corresponding Author: Ningtyas Orilina Argawati tyas.orilina@yahoo.com

Received: 1 July 2019 Accepted: 18 July 2019 Published: 31 July 2019

Publishing services provided by Knowledge E

(c) Ningtyas Orilina Argawati and Lilis Suryani. This article is distributed under the terms of the Creative Commons

Attribution License, which

permits unrestricted use and redistribution provided that the original author and source are credited.

Selection and Peer-review unde the responsibility of the AICLL 2019 Conference Committee.

\section{G OPEN ACCESS} the research are 40 students of first semester of IKIP Siliwangi. Observation sheet, speaking test, and interview were used to collect the data. The data, then, were analyzed qualitatively using descriptive statistic and data triangulation. Based on the result, the implementation of IGA could develop the students' ability in speaking. Besides, there were three strengths and one weakness in implementing IGA; they are: IGA could motivate the students in learning better, it coud help the students to improve the score of speaking, and it activated the students to work in a pair well. In other word, this method created a chance for them to help each other. Besides, the students could solve the problem by exchanging information. However, the weakness found in this research was this method, IGA, needed much time to apply so that the researchers felt that it was hard to use perfectly due to the limited time.

Keywords: Information Gap Activity, Speaking Ability, and Classroom Action Research.

\section{Introduction}

Students are prepared to master four language skills and one of them is speaking skill. Richard and Renandya (2002) explain that speaking is one of the main elements in communication. Speakers can express their ideas by speaking effectively. It is supported by Oxford (1998), speaking as knowledge people say or talk in a form of speech/utterances in a language in order to express their ideas, feelings by combining words. Nevertheless, the students faced difficulties in delivering their ideas in front of the classroom. This is in line with (Pinter, 2006), she states that learning to speak fluently and accurately is 
one of the greatest challenges for all language learners. On the other hand, speaking can be biggest problem that encounter the students' learning.

Many research have already been conducted on improving students' speaking ability with using various method and techniques. One was conducted by Trisna and Nasution (2018). They tried to develop macromedia flash as a material to teach speaking; the main aim of this development was the improvement of the students' speaking skill. Another research was done by Quaidy and Alpard (2018). They looked for some appropriate techniques which the teacher can use to teach speaking in their classroom.

IGA or information gap activity is one of the methods that can help the students to encourage their motivation to speak up. According to Li (2005), an information gap is a situation in which there is a communication between two or more people and where information is known only to some of the people present. In addition, Harmer (2007) stated that Information Gap Activity is an activity where the two speakers have different bits of information, and they can only complete the whole picture by sharing information because they have different information, there is a "gap" between them. This is in line with Walz (1996) as cited in Hood (2006), each person possesses information that is unknown to others. To overcome the gap we must communicate with others and all students participate equally \& actively. The students are motivated to speak in a pair and they can help each other. IGA also can make the students learn actively and it can make better teaching and learning process. So, the researchers tried to implement Information Gap Activity (IGA) to solve those problems and to discover the strengths and weaknesses of IGA in teachings speaking.

\section{Literature Review}

Speaking is the first skill that other people can identify the speakers' ability. Speaking in a second or foreign language has been often viewed as the most demanding of the four skills (Bailey and Savage, 1994; cited in Lazaraton, 2001). Based on the criteria of successful speaking, the students could not achieve those criteria, including the students of first semester of IKIP Siliwangi. The students could not express their ideas because they did not know to say it in English. They were afraid to speak up, and to participate in learning process.

Nunan (1999) states that there are some challenges in teaching oral skill in EFL classroom namely lack of motivation, and they tend to use their first language. In addition, Suryani (2015) argues that most of the students are reluctant to speak up and they have low motivation. In other words, the students are not active in the 
classroom and they tend to keep silent in learning. So, it is not indicated that teaching speaking will work effectively. This is similar with Ur (2000), she says that there are some characteristics of a successful speaking activity, they are learners talk a lot, participation, motivation is high, and language is acceptable. It means that the students could not express their ideas in English as foreign language and it causes they have low motivation in learning.

Based on explanation above, Information Gap Activities is offered to solve those problems. It provides students interaction and meaningful interaction with peers (Lee and VanPatten, 1995). It is related to Vygotsky's theory (1978) that social interaction is the basis of human cognition and learners create and modify meaning, they stand a better chance of internalizing the language than those who produce it only to display correct language forms. This is in line with Scrivener (2005), IGA can motivate and stimulate students by exchanging information. He adds that gap of information between people give the students need and desire to communicate each other. Richards and Schmidt (2014) define that an Information-gap task is an activity in language teaching where students are missing information necessary to complete a task or solve a problem, and must communicate with their classmates to fill in the gaps. Besides, Nunan (1992) argues that activities in IGA are not exercises, but contexts in which students can use language to find out about things they genuinely need to know and share ideas.

Based on the explanation above, IGA is activity that be done in pairs to complete particular task. There is a gap information between one student to another student. They have to work in a pair to complete each other's, so the students are forced to speak up. This activity can encourage the students' motivation and drill the students to discover new information by asking to his/her friends. At the end of learning, the students can be more active in learning.

\section{Research Method}

This research employed classroom action research. Classroom action research was chosen to improve learning. Action research designs are systematic procedures done by teachers (or other individuals in an educational setting) to gather information about, and subsequently improve, the ways their particular educational setting operates, their teaching, and their student learning (Creswell, 2012; Kemmis, McTaggart and Nixon, 2013). This research focuses on classroom setting. Burns (2010) cited in Argawati (2017), action research is part of aboard movement that has been going in education 
generally for some time and related to the ideas of reflective practice and the teacher as researcher.

Classroom action research consists of four steps; they are planning, action, observation, and reflection (Hopkins, 1992). This research was conducted 2 cycles and each cycle consists of three meetings. The participants of the research are 30 students of forth semester of IKIP Siliwangi. The first researcher acted as lecturer who implemented IGA and the second researcher acted as an observer who observed teaching and learning process. Observation sheet, speaking test, and interview were used to collect the data. Observation was done by an observer, while speaking test was conducted after teaching using IGA. Interview also was done after second cycle to get students' perception about IGA in learning. The data, then, were analyzed qualitatively using descriptive statistic and data triangulation.

\section{Result and Discussion}

This part can be divided into two parts, the first is the implementation of IGA and the second is the strengths and weakness of IGA in learning speaking.

\subsection{The implementation of information gap activity (IGA)}

IGA was implemented to help the students is learning speaking. There were 3 cycles that were implemented in this research, they are: pre cycle, cycle 1, and cycle 2.

\subsubsection{Pre cycle}

Pre cycle was implemented on Tuesday September 12, 2017. In this part, the researchers did speaking test for the students. Most of the student faced difficulties in answering the questions. The mean score of the students was 61 . Based on the data of the mean score, the score was not really good. Therefore, the researchers discussed how to solve this problem by offering Information Gap Activity in teaching speaking for the students.

\subsubsection{Cycle 1}

Each cycle consists of four steps, which are planning, action, observation, and reflection. 


\section{Planning}

Pre cycle data were used as reflection to make a new planning in teaching speaking. The researchers designed a lesson plan and teaching procedure in teaching and learning process in the classroom. The researchers chose two materials, find out differences and direction. The first researcher acted as a lecturer and the second researcher acted as an observer. In the first cycle, the researchers implemented three meetings.

\section{Action}

The first meeting of cycle one was conducted on Tuesday September 19, 2017. At the first meeting, the lecturer explained what Information Gap Activity is, and the procedure in implementing IGA. The lecturer explained about personal identity materials, and then she gave two kinds of worksheet to the students, which are worksheet $A$ and worksheet B. Both of the worksheet was not complete each other's. The students should work in a pair to complete each other.

The second cycle was conducted on Tuesday September 26, 2017. The lecturer reviewed the materials and asked them about their family tree. The lecturer drew a family tree and asked the students to describe and explain their family members. The lecturer then gave each student a picture of the same family tree with some differences (Picture A and Picture B). The lecturer asked the students to look and analyze the picture in five minutes, and then students have to exchange information to complete their family tree. By asking each other, the students can complete the information gap. Sharing information could encourage the students to talk more with his/her friends.

The third meeting was conducted on Tuesday October 3, 2017. Speaking test was implemented in this part. The mean score of the students was 68 . In other words, there was a good improvement from pre cycle to cycle 1. Besides, the students have positive effect.

\section{Observation}

The observer observed teaching and learning process in the classroom by using observation sheet and she observed what the students did and what the lecturer did. The result of observation sheet would discuss with the lecturer in the next step of classroom action research. There were some strengths and weaknesses in this cycle and it could be a guide line to the next cycle. 


\section{Reflection}

The result of first cycle showed a good improvement, it can be seen from the mean score and the students' behavior in the classroom. Most of the students really like IGA method and they are more active to do their task in a pair. They can help each other too. Nevertheless, the observer and the researcher found that some of the students were still confused how to do their task, so controlling and helping from the lecturer is more needed in the next cycle. Some of the students were really difficult to ask the question and they tend to speak in their mother tongue. It was caused that both of the students are silent students. Therefore, the lecturer has to select the appropriate partner based on their activeness in the classroom. So, the active student can help silent student to speak up and it can encourage the students' motivation to speak up in English.

\subsubsection{Cycle 2}

Cycle 2 was conducted as reflection from the first cycle. The weaknesses in the first cycle were revised to get better improvement. Cycle two covered four steps as stated in cycle 1.

\section{Planning}

This step was used to revise some of the weaknesses in cycle 1. In this section, the lecturer changed the partner of the students when she/he did work in a pair. The lecturer made a new partner to help them in speaking. This is used in order to solve the problems and they can help each other.

\section{Action}

Cycle 2 was conducted 3 meetings as stated in cycle 1 . The first meeting was conducted on Tuesday October 10, 2017. The lecturer reviewed and asked the students' the previous materials. Then, the lecturer introduced direction material. The students were given a map worksheet. The lecturer asked the students to read the map. The lecturer gave two kinds of worksheet. The lecturer wrote down the list of destination in the board and gave an example to the students. The students worked in a pair and student $A$ asked the destination to student B and students B gave directions to student A. Student B then followed the direction until she / he got the right destination. While implementing 
IGA, the lecturer controlled language production and participation between student $A$ and $B$. The lecturer has to make sure that students do not let their partners see each other's notes or information.

The second meeting was conducted on Tuesday October 17, 2017. The students were given a shopping gap list. The students got two kinds of shopping list worksheet $A$ and B. Each student can share his/her information to his/her partner. The students asked about the shopping list that they got and tried to complete the gap by asking to his/her partner.

The third meeting was conducted on Tuesday, October 24 2017. The students got the speaking test and the mean score was 75. It was indicated that the students got good improvement from pre cycle to second cycle.

\section{Observation}

The observer found that the students got good improvement not only from score but also from their perspective too. The students had a better learning in speaking and they could motivate themselves to be more active in teaching and learning process in the classroom.

\section{Reflection}

Based on the observation, second cycle had a better achievement. Below is the detail improvement of students speaking score:

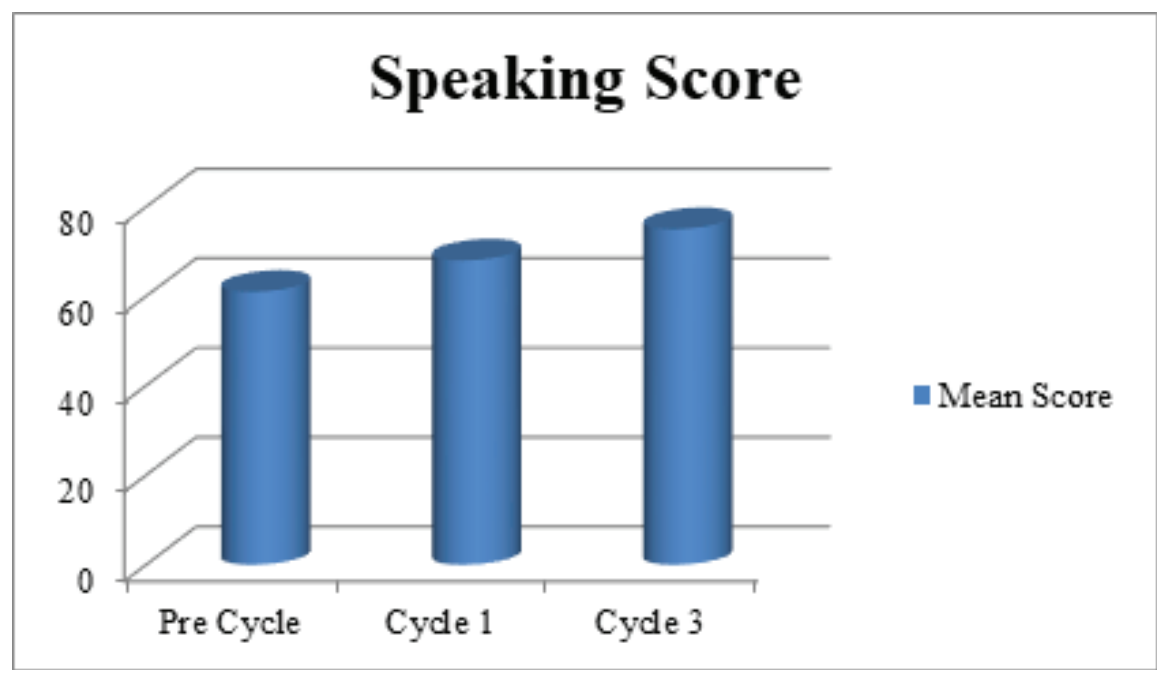

The data show that in the pre cycle, the mean score of the students was 61, the first cycle was 68 , and the second cycle was 75 . It can be seen there was an improvement 14 
point from pre cycle to second cycle. It is supported by Ghofur, and Fuqaha (2015), IGA could help the students increase their scores. Nevertheless, implementing IGA needed more time, so limited time could be the weakness in implementing this method.

\subsection{The strengths and weakness of IGA in learning speaking}

The result showed that there were four strengths and one weakness in implementing IGA; they were:

Firstly, Information Gap Activity (IGA) could motivate the students in learning better. It was indicated from the observation and interview. IGA helped silent students to talk more, and it could encourage their motivation. Some of the students, who had low motivation to talk at the beginning of cycle, they changed it and they tried to talk to complete their task in the first and second cycle. It is supported by Scrivener (2005), IGA can motivate and stimulate students by exchange information.

Secondly, IGA activated the students to work in a pair well. In other word, this method created a chance for them to help each other. Active students could help the students who were not really active, so they could share and helped each other. The silent students were motivated to talk because the stimulus from active students. This is in in line with Walz (1996) as cited in Hood (2006), all students participate equally \& actively when they complete information gap.

Thirdly, IGA could help the students to improve the score of speaking and meaningful learning. It is similar with Lee and VanPatten (1995), Information Gap Activities provide students interaction and meaningful interaction with peers. The students learn contextual learning. Besides, the implementation of IGA could improve the mean score from pre cycle to second cycle. Most of the students got higher score at the last cycle.

Fourthly, the students could solve the problems by asking gap information to his/her friends. It is supported by Richards and Schmidt (2014) IGA can solve a problem because the students have to communicate with their classmates to fill in the gaps.

Besides, the weakness found in this research was this method, IGA, needed much time to apply so that the researchers felt that it was hard to use perfectly due to the limited time. Some of the students needed more time to analyze the worksheet and to create the questions. 


\section{Conclusion}

This research can be concluded that the implementation of IGA could develop the students' ability in speaking. The students got good improvement in each cycle. The means core of pre cycle was 61, the first cycle was 68 , and the second cycle was 75 . Besides, there were three strengths and one weakness in implementing IGA; they were: Firstly, IGA could motivate the students in learning better. Information gap activities make students interaction and meaningful context. Secondly, IGA activated the students to work in a pair well. In other word, this method created a chance for them to help each other. Thirdly, IGA coud help the students to improve the score of speaking. Besides, the weakness found in this research was this method, IGA, needed much time to apply so that the researchers felt that it was hard to use perfectly due to the limited time.

\section{References}

[1] Argawati, O.A. (2017). Think-Pair-Share: Its implementation to improve students' capability on understanding grammar on the second semester students of STKIP Siliwangi. JEOPALLT (Journal of English pedagogy, linguistics, literature, and teaching, volume 5 no 1, July, 1-10.

[2] Creswell, J.W. (2012). Educational research. Buston: Pearson Education.

[3] Ghofur, A., and Fuqaha, A. (2015). Using information gap activity to increase students' speaking skill. OKARA Journal, volume 1, Mei, 73-82.

[4] Harmer, J. (2007). How to teach English. Essex: Pearson Education Limited.

[5] Harmer, J. (2007). The practice of language teaching. Essex: Pearson Education Limited.

[6] Hood, S.J. (2006). Using information gap activities to improve English Learners' Oral Language Proficiency. Portland: University of Portland.

[7] Hopkins, D. (1992). A teacher's guide to classroom research. UK: St. Edmunds burry Press Ltd.

[8] Kemmis, S., McTaggart, R., \& Nixon, R. (2013). The action research planner: Doing critical participatory action research. Springer Science \& Business Media.

[9] Lazaraton, A. (2001). Teaching oral skills. In Celce Murcia,M. Teaching English as a Second or Foreign Language. Melbourne: Heinle \& Heinle.

[10] Lee, J., \& VanPatten, B. (1995). Making communicative language teaching happen. New York: McGraw. Hill. 
[11] Li, Y. (2005). Speaking Activities: Five Features. US-China Foreign Language, 9, III, page 71-75

[12] Nunan, D. (1992). Designing task for the communicative classroom. New York: Cambridge University Press.

[13] Nunan, D. (1999). Second language teaching and learning. Massachusetts: Newbury House.

[14] Oxford, L.R. (1990). Language learning strategies. New York: Newbury House.

[15] Pinter, A. (2006). Teaching young language learners. New York: Oxford University Press.

[16] Quaidy, G. Milla, \& Alpard, Haykal. (2018). The Appropriate Technique In Enhancing Students' Capability In Speaking English. Proceeding of the 1st Annual International Conference on Language and Literature Vol 1, No 1: AICLL April 2018.

[17] Richard, J. C., and Renandya, W.A. (2002). Methodology in language teaching an anthology of current practice. Trumpington Street: Cambridge University Press.

[18] Richards, J. C., \& Schmidt, R. W. (2014). Language and communication. Routledge.

[19] Scrivener, J. (2005). Learning teaching: the essential guide to English language teaching. Macmillan Education.

[20] Suryani, L. (2015). The effectiveness of role play in teaching speaking. ELTIN Journal, October, volume 3/II, 106-109.

[21] Trisna, Ayu., \& Nasution, R. Shibha. (2018). Developing Macromedia Flash For Teaching Speaking Materials For Students. Proceeding of the 1st Annual International Conference on Language and Literature Vol 1, No 1: AICLL April 2018.

[22] Ur, P. (2000). Successful of speaking. Cambridge: Cambridge University Press.

[23] Vygotsky, L. 1978. Interaction between learning and development. Readings on the development of children, 23(3), 34-41. 